\title{
The effects of agrotechnological factors on winter wheat yield in humid cropyear
}

\author{
Vári Enikő-Vad Attila-Pepó Péter \\ Institute of Crop Science, Faculty of Agricultural and Food Sciences and Environmental Management, Centre for Agricultural and Applied \\ Economic Sciences, University of Debrecen \\ H-4032 Debrecen, Böszörményi street 138. \\ e-mail: eniko.vari@gmail.com
}

Keywords: winter wheat, forecrop, fertilization, plant protection, yield

SUMMARY

The effects of crop rotation, nutrien supply and crop protection technologies, as well as the appearance of the main ear-and leafdiseases (powdery mildew, helminthosporium leaf spot, leaf rust, fusarium) were studied on the crop yields of winter wheat variety $M V$ Pálma during the 2009/2010 crop year. The experiments were conducted in triculture (pea - wheat - corn) and biculture (wheat - corn), at five nutrition levels, with the use of three crop protection technologies (extensive, conventional and intensive) at the Látókép Research Site of the University of Debrecen, Centre of Agricultural Sciences. Our results proved that the appearance of leaf- and ear-diseases were significant in the wheat cultures during the 2009/2010 crop year, because of the rainy, warmer than usual weather, the lodging, and the huge vegetative mass developed. The most severe infections by the four examined diseases after pea and corn pre-crops were observed at extensive crop protection levels, when fertilizers were used at the highest dose.

Following corn pre-crop, in the case of all the three crop protection technologies the maximum rate of wheat yield results were achieved at $N_{150}+P K$ level. The highest yield was reached at intensive crop protection level $\left(6079 \mathrm{~kg} \mathrm{ha}{ }^{-1}\right)$. In triculture, in case of all the three crop protection technologies the maximum yields were achieved at $N_{50}+P K$ level; in extensive technology $5041 \mathrm{~kg} \cdot \mathrm{ha}^{-1}$ yield, in conventional technology $6190 \mathrm{~kg} \mathrm{ha}^{-1}$ yield was realised, while in the intensive technological model the yield was $7228 \mathrm{~kg} \mathrm{ha-1}$.

The relationship between yield and fertilizer amounts, the rate of pathogen contaminations, crop protection technologies and pre-crops was defined with correlation analysis in case of different crop rotations during the 2009/2010 crop year. Based on the results of the experiment, we found that in stands after corn pre-crop strong positive correlation was established between the crop protection level and the crop yield (0.543), the nutrient levels and the emergence of the four examined pathogens, and between the nutrient levels and the yield (0.639). Extremly strong positive correlation was observed between crop protection and yield (0.843) in triculture. Strong positive correlation was detected between the nutrient levels and the presence of the four examined pathogens, as well as between nutrient and lodging (0.688). Strong negative correlation was between the crop protection level and the four examined diseases both in biculture and triculture.

\section{Review of scientific literature}

The yield of winter wheat is affected by many factors such as biological, genetical, ecological conditions and agrotechnological factors.

The climate of Hungary is suitable for wheat production, but there are more favourable and less favourable production sites (NAGY, 1981). The importance of climate factors is decisive for wheat yield. Crop fluctuations are principally caused by climate factors, especially the lack of precipitation (RADICS, 2003). Precipitation is the most variable element of climate, its uncertanity can be characterised by the fact that in the most humid years the amount of precipitation can be three times higher that in the driest years (BOCZ, 1996). SZÁSZ (1973) states that high crop yields can only be obtained when climate conditions - primarily water supply - satisfy the plants' needs. MÁRTON (2004) searched the effects of fertilizers, liming and precipitation on winter wheat yield and established that in humid years the crop yield was lower than in case of drought damage. The optimal precipitation and the corresponding yields varied between $449-495 \mathrm{~mm}$ an 1.7-3.4 $\mathrm{t} \mathrm{ha}^{-1}$. In humid cropyear the high precipitation increases the damage caused by infections. The rainy and cold summer of year 1933 has assisted to the appearance of stripe rust (Puccinia striiformis) (UBRIZSY, 1965). According to PEPÓ (2004), the degree of leaf- and ear- diseases is determined by the season. When the precipitation ranged between 200-250 $\mathrm{mm}$ during spring and at the beginning of summer (April, May, June), the diseases occured significantly. KOVÁCS (1996) states that the protection against Fusarium ear blight is determined by the number of rainy days from ear formation till harvest. If this values ranges between 20-23 days, serious diseases can be expected.

The baking quality of wheat is determined up to $25 \%$ by the elements of direct effect (especially fertilization and plant protection), and up to $16 \%$ by the elements of indirect effects (pre-crop, sowing, harvest) of the agrotechnological factors (PEPÓ, 2005). Among the external agrotechnological factors, nutrition supply has the greatest effect on the wheat quality in the given cropyear, as winter wheat is one of the most demanding and responsive culture (GYÖRI ÉS GYÖRINÉ MILE, 1998). The quantity of fertilizer doses applied and their effectiveness are affected by many factors, such as season, soil cultivation and soil properties. Nutrient content, nutrient supply capacity of soil and nutrient supplement of precrops should also be taken into consideration (PEPÓ ÉS RUZSANYI, 1990). The nutrient dose modifying effect of precrop is complex. The best precrops are those harvested in the summer, such as leguminous crops (except soyabean), rape, hemp. The harvesting time of these crops lasts from July till the middle of August (GYỎRI and GYÖRINÉ MILE, 1998). BOCZ and SÁRVÁRI (1981); VÁRNAI et al. (1985) emphasize the fact that wheat yield can be higher by 0.8-0.9 t/ha after 
pea, and this amount can be higher by $0.3-0.5$ t/ha after corn, compared to wheat monoculture. According to KÁPOSZTA's (1971) results if wheat is grown in consecutive years the fertilizer, expecially the N-demand increases. However, the present of excessive $\mathrm{N}$ amount over the fiziological optimum causes excessive development of vegetative mass, weakens the plant tissue and enhances mycosis (BOCZ, 1996). Breeding for resistance against fusarium, powdery mildew, rust- and foot-deseases is considered the most important stragegy in winter wheat production (PEPÓ ÉS RUZSÁNYI, 1990).

\section{Materials and Methods}

The experiments were conducted as part of the long-term trial adjusted by Prof. Dr. László Ruzsányi in 1983, in triculture (pea - wheat - corn) and biculture (wheat - corn), at five nutrition levels, with the use of three crop protection technologies (extensive, conventional and intensive) at the Látókép Research Site of the Centre of Agricultural Scienses, University of Debrecen. The research area is located on the Hajdúság loess ridge, $15 \mathrm{~km}$ from Debrecen, along Route 33. The wheat variety used in the long-term trial was Mv Pálma, which was sown at 5.8 million germs/ha.

The soil of the research site is plain and homogen, its genetic soil type is calciferous chernozem. Starting state data show that the soil-physical category of the soil is loam, its $\mathrm{pH}$ value is almost neutral, phosphorus supply is medium, and potassium supply is medium - good. Humus content is medium, the thickness of humus layer is about $80 \mathrm{~cm}$. Estimated depth to groundwater is $3-5 \mathrm{~m}$.

The agrotechnical interventions applied in the trial met the requirements of modern wheat cultivation. In the extensive, conventional and intensive plant protection technologies the crops were protected against weeds with the combination of Solar 0.2 1/ha + Duplosan DP 1.5 1/ha + Mezzo $10 \mathrm{~g} / \mathrm{ha}$. In extensive plant protection technology no pest or disease control measures were applied. In the stock where conventional plant protection technology was applied, Tango Star was used in a 0.8 1/ha dose (May 25th, 2010.), while pest control measures were not applied. Regarding the intensive technology, Tango Star (May 3rd, 2010) and Juwel TT (May 25th, 2010) were applied against pathogens in $0.8 \mathrm{l} / \mathrm{ha}$ and $1.2 \mathrm{l} / \mathrm{ha}$ doses, respectively, but pest prevention measure was not applied either.

The weather of crop year 2009/2010 was significantly extreme in respect of winter wheat growth. Following the dry weather of early autumn the precipitation of the whole crop year (exept March) was much higher than the average. The rainy weather set in at the end of October was favourable in respect of the growth, the strengthening and the preparation for winter of the wheat cultures. The wheat stands tolerated well the severe winter weather under snow cover. Precipitation, spring and early summer weather were prosperous for the vegetative growth of the crops, however, owing to the huge amount of precipitation the occurence of plant diseases and lodging were significant. During the humid cropyear the yield results were average or less than average, depending of the treatments. Table 1. summarizes the tendency of the meteorological factors during the crop year of 2009/2010.

Table 1.

Meteorological parameters in the vegetation period of winter wheat (precipitation, mean monthly temperature, Debrecen, 2010.)

\begin{tabular}{|c|c|c|c|c|c|c|c|}
\hline \multirow{3}{*}{ Month } & \multicolumn{3}{|c|}{ Precipitation $(\mathrm{mm})$} & \multirow{3}{*}{ Month } & \multicolumn{3}{|c|}{ Temperature $\left({ }^{0} \mathrm{C}\right)$} \\
\hline & \multirow{2}{*}{ 2009/2010. } & \multirow{2}{*}{$\begin{array}{l}\text { 30-year } \\
\text { average }\end{array}$} & \multirow{2}{*}{$\begin{array}{c}\text { Difference } \\
2010 .\end{array}$} & & \multirow{2}{*}{ 2009/2010. } & \multirow{2}{*}{$\begin{array}{l}\text { 30-year } \\
\text { average }\end{array}$} & \multirow{2}{*}{\begin{tabular}{|c|} 
Difference \\
2010. \\
\end{tabular}} \\
\hline & & & & & & & \\
\hline October & 79,3 & 30,8 & 48,5 & October & 11,4 & 10,3 & 1,1 \\
\hline November & 78,3 & 45,2 & 33,1 & November & 7,6 & 4,5 & 3,1 \\
\hline December & 54,9 & 43,5 & 11,4 & December & 2,3 & $-0,2$ & 2,5 \\
\hline January & 48,8 & 37 & 11,8 & January & $-1,1$ & $-2,6$ & 1,5 \\
\hline February & 58,6 & 30,2 & 28,4 & February & 0,5 & 0,2 & 0,3 \\
\hline March & 14,4 & 33,5 & $-19,1$ & March & 7,6 & 5 & 2,6 \\
\hline April & 83,9 & 42,4 & 41,5 & April & 11,6 & 10,7 & 0,9 \\
\hline May & 111,4 & 58,8 & 52,6 & May & 16,6 & 15,8 & 0,8 \\
\hline June & 100,9 & 79,5 & 21,4 & June & 19,7 & 18,8 & 0,9 \\
\hline $\begin{array}{c}\text { Total annual } \\
\text { precipitation }(\mathrm{mm})\end{array}$ & 630,5 & 400,9 & 229,6 & $\begin{array}{l}\text { Mean annual temperature } \\
\left({ }^{\circ} \mathrm{C}\right)\end{array}$ & 8,47 & 6,94 & 1,53 \\
\hline
\end{tabular}

\section{Results and Discussion}

The effect of pre-crops, fertilization and crop protection technologies were studied for the appearance of leafand ear-deseases and for winter wheat yield results.

\section{The effects of the treatmenst on the pathological condition of wheat}

Powdery mildew, helminthosporium leaf spot (HTR), leaf rust and fusarium contamination levels were examined during 2009/2010 crop year, using three plant protection technologies (extensive, conventional, intensive) of different intensity. After corn pre-crop the powdery mildew contamination of the control plots was 
the lowest (2-5\%) in case of the different plant protection technologies during 2009/2010 crop year. Contamination gradually increased with the increasing fertilizer doses; these doses are summarized in Table 2. The rate of helminthosporium leaf spot was $5-12 \%$ on the control plots. HTR-contamination showed increase with increasing nutrient levels, the most severe contamination was detected at the highest nutrient level; in case of extensive plant protection technology this reached $38 \%$, in the conventional technological model the contamination was $29 \%$ and in intensive technology it was $15 \%$. We can state that the highest contamination (24\%) by leaf-cust was observed in case of extensive technology near the highest fertilizer doses. Severe ear fusarium contamination appeared in wheat stocks during 2010 due to the persistent precipitation and the humid air during ear formation - flowering and ripening. The degree of fusarium contamination reached 3-8\% even on the control plots. Similar to the increasing trend of the other infections, this rate also showed further increase together with the increasing nutrient levels and reached 13-26\% at $\mathrm{N}_{200}+\mathrm{PK}$ nutrient level.

Table 2.

Effect of fertilisation and plant protection technology on leaf and ear diseases of winter wheat in a biculture (Debrecen, 2010.)

\begin{tabular}{|c|c|c|c|c|c|}
\hline \multirow{2}{*}{$\begin{array}{l}\text { Plant protection } \\
\text { technology (A) }\end{array}$} & \multirow{2}{*}{$\begin{array}{l}\text { Fertiliser rate }\left(\mathrm{kg} \mathrm{ha}^{-1}\right) \\
\text { (B) }\end{array}$} & \multicolumn{4}{|c|}{2010.} \\
\hline & & Powdery mildew & HTR & Leaf rust & Spike fusarium \\
\hline \multirow{5}{*}{ Non-intensive } & $\varnothing$ & 5 & 12 & 6 & 8 \\
\hline & $\mathrm{N}_{50}+\mathrm{PK}$ & 8 & 17 & 10 & 13 \\
\hline & $\mathrm{N}_{100}+\mathrm{PK}$ & 12 & 29 & 14 & 17 \\
\hline & $\mathrm{N}_{150}+\mathrm{PK}$ & 15 & 35 & 22 & 22 \\
\hline & $\mathrm{N}_{200}+\mathrm{PK}$ & 16 & 38 & 24 & 26 \\
\hline \multirow{5}{*}{ Average } & $\varnothing$ & 2 & 10 & 2 & 6 \\
\hline & $\mathrm{N}_{50}+\mathrm{PK}$ & 4 & 13 & 5 & 9 \\
\hline & $\mathrm{N}_{100}+\mathrm{PK}$ & 9 & 19 & 8 & 13 \\
\hline & $\mathrm{N}_{150}+\mathrm{PK}$ & 11 & 27 & 12 & 18 \\
\hline & $\mathrm{N}_{200}+\mathrm{PK}$ & 12 & 29 & 13 & 20 \\
\hline \multirow{5}{*}{ Intensive } & $\varnothing$ & 2 & 5 & 1 & 3 \\
\hline & $\mathrm{N}_{50}+\mathrm{PK}$ & 3 & 8 & 2 & 6 \\
\hline & $\mathrm{N}_{100}+\mathrm{PK}$ & 4 & 12 & 4 & 10 \\
\hline & $\mathrm{N}_{150}+\mathrm{PK}$ & 5 & 14 & 5 & 12 \\
\hline & $\mathrm{N}_{200}+\mathrm{PK}$ & 5 & 15 & 5 & 13 \\
\hline LSD5\% (A) & & 2,76 & 4,99 & 2,69 & 3,42 \\
\hline LSD5\% (B) & & 1,68 & 2,90 & 1,64 & 2,08 \\
\hline LSD5\% (AxB) & & 2,90 & 5,03 & 2,84 & 3,60 \\
\hline
\end{tabular}

The examined four diseases reached their infection maximum at the highest nutrient level in triculture as well (after pea pre-crop). Among the plant protection technologies, the highest contamination was observed in the extensive technological model; these data are included in Table 3.

Table 3.

Effect of fertilisation and plant protection technology on leaf and ear diseases of winter wheat in a triculture (Debrecen, 2010.)

\begin{tabular}{|c|c|c|c|c|c|}
\hline \multirow{2}{*}{$\begin{array}{l}\text { Plant protection technology } \\
\text { (A) }\end{array}$} & \multirow{2}{*}{$\begin{array}{l}\text { Fertiliser rate } \\
\left(\mathrm{kg} \mathrm{ha}^{-1}\right)(\mathrm{B})\end{array}$} & \multicolumn{4}{|c|}{2010.} \\
\hline & & Powdery mildew & HTR & Leaf rust & Spike fusarium \\
\hline \multirow{5}{*}{ Non-intensive } & $\varnothing$ & 6 & 19 & 9 & 7 \\
\hline & $\mathrm{N}_{50}+\mathrm{PK}$ & 10 & 28 & 14 & 11 \\
\hline & $\mathrm{N}_{100}+\mathrm{PK}$ & 15 & 36 & 21 & 15 \\
\hline & $\mathrm{N}_{150}+\mathrm{PK}$ & 21 & 42 & 29 & 20 \\
\hline & $\mathrm{N}_{200}+\mathrm{PK}$ & 24 & 48 & 31 & 24 \\
\hline \multirow{5}{*}{ Average } & $\varnothing$ & 4 & 14 & 5 & 5 \\
\hline & $\mathrm{N}_{50}+\mathrm{PK}$ & 7 & 19 & 7 & 9 \\
\hline & $\mathrm{N}_{100}+\mathrm{PK}$ & 10 & 26 & 10 & 10 \\
\hline & $\mathrm{N}_{150}+\mathrm{PK}$ & 14 & 30 & 15 & 12 \\
\hline & $\mathrm{N}_{200}+\mathrm{PK}$ & 15 & 32 & 17 & 17 \\
\hline \multirow{5}{*}{ Intensive } & $\varnothing$ & 2 & 7 & 2 & 2 \\
\hline & $\mathrm{N}_{50}+\mathrm{PK}$ & 3 & 9 & 3 & 5 \\
\hline & $\mathrm{N}_{100}+\mathrm{PK}$ & 5 & 14 & 4 & 6 \\
\hline & $\mathrm{N}_{150}+\mathrm{PK}$ & 6 & 17 & 6 & 10 \\
\hline & $\mathrm{N}_{200}+\mathrm{PK}$ & 7 & 18 & 9 & 11 \\
\hline LSD5\% (A) & & 2,57 & 4,91 & 3,42 & 3,04 \\
\hline LSD5\% (B) & & 1,56 & 2,89 & 1,82 & 1,85 \\
\hline LSD5\% (AxB) & & 2,70 & 5,01 & 3,15 & 3,20 \\
\hline
\end{tabular}


The rate of powdery mildew infection reduced in the conventional and intensive crop protection technologies, and was extremely enhanced by the increased fertilizer doses. According to this, the most severe powdery mildew contamination (24\%) was experienced at the highest fertilizer dose in extensive crop protection technology. The same can be stated about helminthosporium leaf spot as well. The disease was redused moderately by simple protection (i.e. usual technology), and significantly by double stock protection (intensive crop protection). Leaf-rust contamination increased continously as well with the increase of fertilizer doses, and achieved the highest value $(31 \%)$ at level $\mathrm{N}_{200}+\mathrm{PK}$ in the extensive crop protection technology. The intensive technology decreased the infection rate efficiently, that is, it was only $9 \%$ even in case of the highest fertilizer dose. Similar results were obtained when fusarium infection was tested as in biculture crop rotation, after corn pre-crop. The contamination rates varied between $2-24 \%$ depending on the crop protection technologies and nutrient treatments. The results proved that the appearance of leaf- and ear-diseases were extremely significant in wheat cultures during the 2009/2010 crop year, owing to the rainy, warmer than usual weather, the lodging, and the huge vegetative mass developed.

\section{The effects of the treatments on winter wheat yield}

The effect of the different crop rotation, nutrient- and crop protection treatments on winter whet yield are summarised in Table 4. Following corn pre-crop, the maximum of wheat yields was achieved at $\mathrm{N}_{150}+\mathrm{PK}$ level, in all three crop protection technologies. The largest yield was obtained in intensive crop protection technology $\left(6079 \mathrm{~kg} \mathrm{ha}^{-1}\right)$, since this was the treatment that most effectively reduced the occurence of diseases, thus the yield reducing effect of diseases was moderate.

In triculture after pea pre-crop, in all three crop protection technologies the maximum rates were achieved at $\mathrm{N}_{50}+\mathrm{PK}$ level; in extensive technology $5041 \mathrm{~kg} \mathrm{ha}^{-1}$ yield, in conventional crop protection $6190 \mathrm{~kg} \mathrm{ha}^{-1}$ yield was realised, while in the intensive technological model the yield was $7228 \mathrm{~kg} \mathrm{ha}^{-1}$.

Having compared the maximum crop yield of the stands after corn and pea precrops, we found that the wheat yield in triculture was 771-1149 $\mathrm{kg} \mathrm{ha}^{-1}$ higher than in biculture. The reason for that is the fact that pea increases the nitrogen supply of the soil, spares its hydrological regime, has favourable effects on the physical and chemical properties, hereby increases yield amount.

Table 4.

Effect of fertilisation and plant protection technology on the yield of the winter wheat in biculture and triculture (Debrecen, 2010.)

\begin{tabular}{|c|c|c|c|}
\hline \multirow{2}{*}{ Plant protection technology (A) } & Fertiliser rate $\left(\mathrm{kg} \mathrm{ha}^{-1}\right)$ & \multicolumn{2}{|c|}{ Yield $\left(\mathrm{kg} \mathrm{ha}^{-1}\right)$} \\
\cline { 2 - 4 } & $\varnothing$ & Biculture 2010. & Triculture 2010. \\
\hline \multirow{4}{*}{ Non-intensive } & $\varnothing$ & 2972 & 4242 \\
\cline { 2 - 4 } & $\mathrm{N}_{50}+\mathrm{PK}$ & 3671 & $\mathbf{5 0 4 1}$ \\
\cline { 2 - 4 } & $\mathrm{N}_{100}+\mathrm{PK}$ & 3842 & 4886 \\
\cline { 2 - 4 } & $\mathrm{N}_{150}+\mathrm{PK}$ & $\mathbf{4 1 7 6}$ & 4742 \\
\cline { 2 - 4 } & $\mathrm{N}_{200}+\mathrm{PK}$ & 3836 & 4530 \\
\hline \multirow{5}{*}{ Average } & $\varnothing$ & 3162 & 4885 \\
\cline { 2 - 4 } & $\mathrm{N}_{50}+\mathrm{PK}$ & 4223 & $\mathbf{6 1 9 0}$ \\
\cline { 2 - 4 } & $\mathrm{N}_{100}+\mathrm{PK}$ & 5292 & 5804 \\
\cline { 2 - 4 } & $\mathrm{N}_{150}+\mathrm{PK}$ & $\mathbf{5 4 1 9}$ & 5645 \\
\cline { 2 - 4 } & $\mathrm{N}_{200}+\mathrm{PK}$ & 5194 & 5367 \\
\hline \multirow{5}{*}{ Intensive } & $\varnothing$ & 3316 & 5607 \\
\hline & $\mathrm{N}_{50}+\mathrm{PK}$ & 4669 & $\mathbf{7 2 2 8}$ \\
\cline { 2 - 4 } & $\mathrm{N}_{100}+\mathrm{PK}$ & 5437 & 6990 \\
\cline { 2 - 4 } & $\mathrm{N}_{150}+\mathrm{PK}$ & $\mathbf{6 0 7 9}$ & 7087 \\
\cline { 2 - 4 } & $\mathrm{N}_{200}+\mathrm{PK}$ & 5648 & 6849 \\
\hline LSD5\% (A) & & 420,91 & 449,63 \\
\hline LSD5\% (B) & & 256,14 & 273,61 \\
\hline LSD5\% (AxB) & & 443,64 & 473,90 \\
\hline
\end{tabular}

\section{The results by Pearson correlation-analysis}

The relationship between yield and fertilizer amounts, the rate of pathogen contaminations, crop protection technologies and precrops during crop year 2009/2010 was defined with correlation analysis in case of different crop rotation technologies.

Table 5. contains the data relating to biculture. Based on the results of the experiment, in cultures after corn precrop strong positive relationship was established between the crop protection technology and the yield (0.543), the nutrient levels and the emergence of the four examined pathogens and between the nutrient levels and the yield amount (0.639). Very strong positive correlation was observed between the fertilizer levels and lodging (0.760). Strong negative correlation was between the crop protection technology and the four examined 
diseases. The correlation between the specific technology was lowest with fusarium and highest with leaf-rust infection.

Table 6. contains the results by Pearson's correlation-analysis relating to triculture. Very strong positive correlation was observed between the crop protection technology and the yield (0.843). Strong positive correlation was observed between the nutrient levels and the emergence of the four examined pathogens, as well as between the nutrient supply and lodging (0.688). Strong negative correlation was found between the crop protection technology and the four examined diseases, as well as between the yield and HTR- infection (-0.537) and leaf-rust infection (-0.553). Moderate negative correlation was between the yield amount and fusarium (0.382) and powdery mildew (0.497) infection, respectively.

Table 5.

Correlation between the analysed parameters in the biculture (Debrecen, 2010.)

\begin{tabular}{|c|c|c|c|c|c|c|c|c|}
\hline & $\begin{array}{c}\text { Plant } \\
\text { protection } \\
\text { technology }\end{array}$ & $\begin{array}{c}\text { Fertiliser } \\
\text { rate }\end{array}$ & Yield & $\begin{array}{c}\text { Powdery } \\
\text { mildew }\end{array}$ & HTR & Leaf rust & $\begin{array}{c}\text { Spike } \\
\text { fusarium }\end{array}$ & Lodging \\
\hline $\begin{array}{c}\text { Plant } \\
\text { protection } \\
\text { technology }\end{array}$ & 1 & 0,000 & $0,543(* *)$ & $-0,620(* *)$ & $-0,605(* *)$ & $-0,686(* *)$ & $-0,516(* *)$ & $0,420(* *)$ \\
\hline $\begin{array}{c}\text { Fertiliser } \\
\text { rate }\end{array}$ & & 1 & 0,639 (**) & 0,619 (**) & $0,672(* *)$ & $0,591(* *)$ & $0,766(* *)$ & $0,760(* *)$ \\
\hline Yield & & & 1 & 0,059 & 0,085 & $-0,050$ & 0,228 & $0,792(* *)$ \\
\hline $\begin{array}{c}\text { Powdery } \\
\text { mildew }\end{array}$ & & & & 1 & $0,923(* *)$ & $0,926(* *)$ & $0,864(* *)$ & 0,151 \\
\hline HTR & & & & & 1 & $0,924(* *)$ & $0,896(* *)$ & 0,197 \\
\hline Leaf rust & & & & & & 1 & $0,859(* *)$ & 0,081 \\
\hline $\begin{array}{c}\text { Spike } \\
\text { fusarium }\end{array}$ & & & & & & & 1 & $0,349(* *)$ \\
\hline Lodging & & & & & & & & 1 \\
\hline
\end{tabular}

Correlation between the analysed parameters in the triculture (Debrecen, 2010.)

\begin{tabular}{|c|c|c|c|c|c|c|c|c|}
\hline & $\begin{array}{c}\text { Plant } \\
\text { protection } \\
\text { technology }\end{array}$ & $\begin{array}{c}\text { Fertiliser } \\
\text { rate }\end{array}$ & Yield & $\begin{array}{c}\text { Powdery } \\
\text { mildew }\end{array}$ & HTR & Leaf rust & $\begin{array}{c}\text { Spike } \\
\text { fusarium }\end{array}$ & Lodging \\
\hline $\begin{array}{c}\text { Plant } \\
\text { protection } \\
\text { technology }\end{array}$ & 1 & 0,000 & $0,843(* *)$ & $-0,652(* *)$ & $-0,735(* *)$ & $-0,727(* *)$ & $-0,568(* *)$ & 0,461 (**) \\
\hline $\begin{array}{c}\text { Fertiliser } \\
\text { rate }\end{array}$ & & 1 & 0,143 & $0,632(* *)$ & $0,585(* *)$ & $0,567(* *)$ & $0,709(* *)$ & $0,688(* *)$ \\
\hline Yield & & & 1 & $-0,497(* *)$ & $-0,537(* *)$ & $-0,553(* *)$ & $-0,382(* *)$ & $0,486(* *)$ \\
\hline $\begin{array}{l}\text { Powdery } \\
\text { mildew }\end{array}$ & & & & 1 & $0,923(* *)$ & $0,939(* *)$ & $0,901(* *)$ & 0,085 \\
\hline HTR & & & & & 1 & $0,936(* *)$ & $0,896(* *)$ & 0,047 \\
\hline Leaf rust & & & & & & 1 & $0,896(* *)$ & $-0,039$ \\
\hline $\begin{array}{c}\text { Spike } \\
\text { fusarium }\end{array}$ & & & & & & & 1 & 0,152 \\
\hline Lodging & & & & & & & & 1 \\
\hline
\end{tabular}




\section{REFERENCES}

1. BOCZ E. (1996): Szántóföldi növénytermesztés. Mezőgazda Kiadó. Budapest. 52-53., 252-253.

2. BOCZ E.-SÁRVÁRI M. (1981): Összefüggés a búza előveteménye, a tápanyagellátása és a terméseredménye között. Növénytermelés 30. 5. 437-445.

3. GYÖRI Z.-GYÖRINÉ MILE I. (1998): A búza minősége és minősítése. Mezőgazdasági Szaktudás Kiadó. Budapest.

4. KÁPOSZTA J. (1971): Az őszi búza termesztése vetésváltásban és monokultúrában. Búzatermesztési kísérletek 1960-1970. Akadémiai Kiadó. Budapest

5. KOVÁCS G. (1996): Növényvédelem. In: Szántóföldi növénytermesztés. Mezőgazda Kiadó. Budapest.

6. MÁRTON L. (2004): A mütrágyázás, a meszezés és a csapadék hatása a rozs, a burgonya, az őszi búza és a triticale termésére. Agrokémia és talajtan. 53. 2004. 3-4. 271-290.

7. NAGY L. (1981): A búzatermesztés területi elhelyezése Magyarországon természeti tényezők alapján. Akadémiai Kiadó. Budapest

8. PEPÓ P. (2004): Évjárat, trágyázás hatása az őszi búzafajták levél- és kalászbetegségeire tartamkísérletben. Növénytermelés. 2004. 53. 6. 559-567.

9. PEPÓ P. (2005): A minőségi és a mennyiségi búzatermesztés kritikus elemei. Gyakorlati Agrofórum. 16. 9. 13-22.

10. PEPÓ P.- RUZSÁNYI L. (1990): Növénytermesztési füzetek 1. Debrecen, ATE

11. RADICS L. (2003): Szántóföldi növénytermesztés, Szaktudás Kiadó Ház, Budapest. 77-78.

12. SZÁSZ G. (1973): A termesztett növények vízigényének és az öntözés gyakoriságának meteorológiai vizsgálata. Növénytermelés. 22. 3. 4.

13. UBRIZSY G. (1965): Növénykórtan 1-2. Akadémiai Kiadó. Budapest.

14. VÁRNAI M.-KADLICSKÓ B.-KRISZTIÁN J. (1985): A vetésváltás hatása az őszi búza termésére agyagbemosódásos barna erdőtalajon. In: Búzatermesztési kísérletek 1970-1980. Szerk.: Bajai Jenő-Koltay Árpád. Akadémiai Kiadó. Budapest. 187191. 